\title{
Evaluation of ergonomic risk in the production line of frozen food products
}

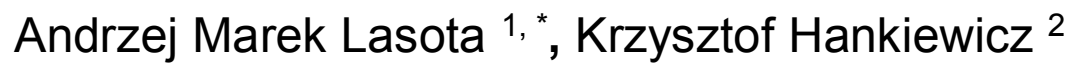 \\ ${ }^{1}$ University of Zielona Gora, Institute of Safety Engineering \& Work Science, 4 prof. Z.Szafrana \\ Street, 65-516 Zielona Góra, Poland \\ ${ }^{2}$ Poznan University of Technology, Chair of Management and Computing Systems, 11 Strzelecka \\ Street, 61-845 Poznan, Poland
}

*am.lasota@o2.pl

\begin{abstract}
The objective of the present study was to assess and investigate the exposure level to risk factors of Work-related musculoskeletal disorders (WRMSDs) in the production line of frozen food products. The workers were evaluated using the Quick Exposure Check (QEC) observational tool. The exposure level to risk factors for the back was classified as very high at one workstation and high at three; shoulder/arm exposure was high at five stations and wrist/hand was high at five stations. The neck was evaluated as being at very high risk at three stations and high at four. The level of exposure to vibration was rated as high at two stations. In total, one workstation required immediate ergonomic intervention and six will require an intervention soon. Work on the production line for frozen food products exposes operators to high levels of risk of developing WRMSDs. Awkward postures, manual handling of heavy loads, repetitive movements and vibration are the suspected risk factors for WRMSDs. Ergonomic interventions are needed to eliminate the risk of exposures to factors contributing to WRMSDs in the production line.
\end{abstract}

\section{Keywords: QEC, risk, WRMSDs, production line.}

\section{Introduction}

Work is often accompanied by physical activity, which may lead to the occurrence of musculoskeletal discomfort among workers in the form of health problems [1, 2, 3]. Furthermore, work-related musculoskeletal disorders (WRMSDs) are a common problem in many countries and often result in limitations at work, loss of working time and absenteeism which in turn generates costs $[4,5,6]$.

Studies have shown that the position of the employee at work, range of motion, force, repetition and duration must be taken into account when categorizing the level of physical activity [7]. The position and movements of the operator at work are important variables that must be taken into account in work safety, because these are the two most important factors that determine the workload on the employee. In addition, the posture of the employee at work is affected by factors such as the type of task carried out, work, work tools, their design and the anthropometric characteristics of workers [8]. Observational methods are commonly used research techniques to estimate the level of exposure to risk factors of WRMSDs. Due to the lack of interference in the work process, low cost and ease of use they are more commonly used in industry [9]. Observational methods used to assess the postural load on the worker may include: Ovako Working Posture Analysing System (OWAS) [10], Rapid Upper Limb Assessment (RULA) [11], Rapid Entire Body Assessment (REBA) [12] and Quick Exposure Check (QEC) [13, 14]. Each has been developed for different purposes and therefore it is used under different conditions in the workplace. Each technique has its own classification system for the operator, which differs from other techniques; this may bring about differences in the final result of the load, depending on the technique used. Their usefulness in the evaluation of exposure to risk of WRMSDs in various industries has been demonstrated through the publication of scientific studies $[15,16-23]$, etc.

From the ergonomic viewpoint, the key elements in the production process affecting workers and their efficient workflow are excessive load, improper position for work, working condition and other elements of an ergonomic subsystem which creates its ergonomic quality [24]. The resulting disturbances in the human system can lead to problems with providing production, quality and an 
increase in costs associated with sickness and absence caused by the negative impact of work on employee health. Therefore, conducting ergonomic assessments becomes crucial in order to detect irregularities that require ergonomic interventions to improve the efficiency of the system. In this study we focused on the production of frozen food products which allowed a detailed investigation of the interaction of employees from every part of the task. The set of methods applied includes interview, task analysis and QEC - a technique of observation that takes into account a self-assessment made by the employee.

The objective of the present study was to assess and investigate the exposure level to risk factors for developing WRMSDs in the production line of frozen food products.

\section{Material and methods}

\subsection{Study design}

This study was conducted at a factory involved in the production of frozen food located in Poland. The study was limited to the production line of frozen food products. The system under assessment included seven stations located at the production line. The study group consisted of 7 people aged from 24 to 52 years. Employees were informed about the study and participated in it as volunteers.

\subsection{Process and task description}

The production process (Fig. 1) consisted of eight main elements. The first phase involved grinding the ingredients followed by the preparation of pastry products, which together with the filling were placed in a former-stuffer. Shaped products were placed on the conveyor belt, which transported them for freezing. Frozen products were moved on a further conveyor belt and then subjected to inspection and sorting. In the next step, they were transported to the package sealing device. Then followed another device to inspect the package for foreign matter. The last stage was the final packaging.

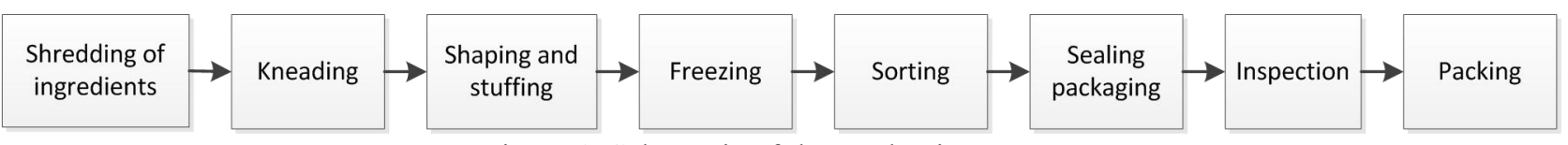

Figure 1. Schematic of the production process

The production line consisted of 7 tasks:

- Workstation 1: Operating the grinding machine. The operator receives a bag of potato dice weighing $20 \mathrm{~kg}$ from the pallet, cuts it open with a knife and pours the contents into the hopper of the grinding machine. Buckets of the processed ingredient are transported to the next workstation. Empty bags are deposited on a prepared pallet. The employee is occupied with adding second ingredients contained in bags weighing $20 \mathrm{~kg}$.

- Workstation 2: Operating the dough kneading machine. The employee is required to add buckets of water to the machine. The prepared dough is then transported to another position by a detachable, rotating part of the machine which is equipped with wheels.

- Workstation 3 and 4: Operation of forming-stuffing machines. Workers prepare the appropriate portions of dough and stuff manually using a knife; these are then piled up to two hoppers for manual forming-stuffing.

- Workstation 5: Inspection and sorting table. Employees inspect and sort the frozen products and separate those that have become joined in the process of freezing.

- Workstation 6: Packaging of product into small packs. The individual packaging units are then packed in cardboard boxes (12 pieces of $0.5 \mathrm{~kg}$ ).

- Workstation 7: Final packing. The employee affixes a label on the packaging of the products, then seals them and moves the cartons $(6 \mathrm{~kg})$ to a pallet placed on the floor.

\subsection{Data collection}

Several techniques were used to collect data in this study: observation, interviews and posture evaluation. Observations of employees carrying out tasks were preceded by interviews with the supervisor and employees in order to understand the process of production, work processes and activities performed by employees 


\subsection{The QEC method and evaluation}

The Quick Exposure Check (QEC) is one of the observational techniques developed for ergonomists and health and safety practitioners in order to investigate musculoskeletal risk factors in workers [14]. QEC evaluates elements of ergonomic risk including: physical, organizational and psychosocial factors. The technique involves an evaluation of the back, shoulder/arm, wrist/hand, and neck, regarding their position and repetitive movement. In addition, QEC takes into account the subjective exposure of employees in relation to: task duration, maximum weight handled, hand force exertion, vibration, visual demand of the task, difficulty to keep up with the work and stressfulness of the work. The advantage of this tool is that the system of assessment takes into account the interaction between expert judgment and self-assessment of the employee. The analysis of tasks using QEC gives exposure scores to specific body parts (Table 1.) and additional factors (Table 2). The exposure levels for back, shoulder/arm, wrist/hand and neck are categorized into four exposure categories: low, moderate, high and very high.

Table 1. The standard exposure scores for the back, shoulder/arm, wrist/hand and neck [13]

\begin{tabular}{lcccc}
\hline \multirow{2}{*}{ Body segment } & \multicolumn{4}{c}{ Exposure level } \\
\cline { 2 - 5 } & Low & Moderate & High & Very high \\
\hline Back (static) & $8-15$ & $16-22$ & $23-29$ & $30-40$ \\
Back (moving) & $10-20$ & $21-30$ & $31-40$ & $41-56$ \\
Shoulder/arm & $10-20$ & $21-30$ & $31-40$ & $41-56$ \\
Wrist/hand & $10-20$ & $21-30$ & $31-40$ & $41-56$ \\
Neck & $4-6$ & $8-10$ & $12-14$ & $16-18$ \\
\hline
\end{tabular}

\begin{tabular}{lcccc}
\hline \multirow{2}{*}{ Exposure factor } & \multicolumn{4}{c}{ Exposure level } \\
\cline { 2 - 5 } & Low & Moderate & High & Very High \\
\hline Driving & 1 & 4 & 9 & - \\
Vibration & 1 & 4 & 9 & - \\
Work pace & 1 & 4 & 9 & 16 \\
Stress & 1 & 4 & 9 & 16 \\
\hline
\end{tabular}

Table 2. The standard exposure scores for driving, vibration, work pace and stress [13]

The overall exposure level $\mathrm{E}$ is calculated as a percentage rate between the actual total exposure score $\mathrm{X}(\mathrm{X}=$ sum of back + shoulder/arm + wrist/hand + neck $)$ and the maximum possible total Xmax. For manual handling tasks, $X \max =176$; for other tasks, $X \max =162$ [25]

Preliminary action levels for the QEC (Table 3) are classified according to four levels of risk: low, medium, high, very high. Low overall exposure scores $(<40 \%)$ indicate acceptable musculoskeletal loading (low risk). For overall exposure scores of $41-50 \%$, further investigation is needed and changes may be required (medium risk). An investigation and changes are required soon for overall exposure scores of $51-70 \%$ (high risk); and immediate investigation and changes are required for overall exposure scores over $70 \%$ (very high risk).

Table 3. Preliminary Action Levels for the QEC [25]

\begin{tabular}{ll}
\hline QEC Score $(\mathrm{E})[\%]$ & Action \\
\hline$<=40$ & acceptable \\
$41-50$ & investigate further \\
$51-70$ & investigate further and change soon \\
$>70$ & investigate and change immediately \\
\hline
\end{tabular}

In this study, the evaluation was carried out during the performance of work by employees.

\section{Results}

In total, 7 employees involved in this study were rated. Table 4 presents the exposure score and Table 5 shows the exposure level of QEC analysis for the back, shoulder/arm, wrist/hand and neck. The results showed that exposure risk for the back was very high at one workstation, high at three stations, and medium at three. For shoulder/arm: for five stations - high and at two stations - medium. 
Exposure levels for the wrist/hand were high at five stations and medium at two. Finally, for the neck: at three stations - very high and at four stations - high.

Table 4. The exposure scores for the back, shoulder/arm, wrist/hand and neck

\begin{tabular}{lccccccc}
\hline \multirow{2}{*}{ Body segments } & \multicolumn{1}{c}{ Workstations } \\
\cline { 2 - 8 } & 1 & 2 & 3 & 4 & 5 & 6 & 7 \\
\hline Back & 42 & 36 & 30 & 26 & 22 & 38 & 40 \\
Shoulder/arm & 38 & 28 & 34 & 34 & 34 & 30 & 32 \\
Wrist/hand & 38 & 34 & 32 & 28 & 34 & 26 & 32 \\
Neck & 14 & 14 & 14 & 14 & 16 & 16 & 18 \\
\hline
\end{tabular}

Table 5. The exposure level for the back, shoulder/arm, wrist/hand and neck

\begin{tabular}{lccccccc}
\hline \multirow{2}{*}{ Body segments } & \multicolumn{7}{c}{ Workstations } \\
\cline { 2 - 7 } & 1 & 2 & 3 & 4 & 5 & 6 & 7 \\
\hline Back & very high & high & medium & medium & medium & high & high \\
Shoulder/arm & high & medium & high & high & high & medium & high \\
Wrist/hand & high & high & high & medium & high & medium & high \\
Neck & high & high & high & high & very high & very high & very high \\
\hline
\end{tabular}

The exposure scores and exposure level for the additional factors: driving, vibration, work pace and stress are shown in Table 6 and Table 7, respectively.

Table 6. The exposure scores for driving, vibration, work pace and stress

\begin{tabular}{llllllll}
\hline \multirow{2}{*}{ Additional factors } & \multicolumn{1}{c}{ Workstations } & \multicolumn{1}{c}{} \\
\cline { 2 - 8 } & 1 & 2 & 3 & 4 & 5 & 6 & 7 \\
\hline Driving & 1 & 1 & 1 & 1 & 1 & 1 & 1 \\
Vibration & 9 & 9 & 1 & 1 & 1 & 1 & 1 \\
Work pace & 1 & 1 & 1 & 1 & 4 & 1 & 1 \\
Stress & 4 & 4 & 4 & 4 & 4 & 4 & 4 \\
\hline
\end{tabular}

Table 7. The exposure level for driving, vibration, work pace and stress

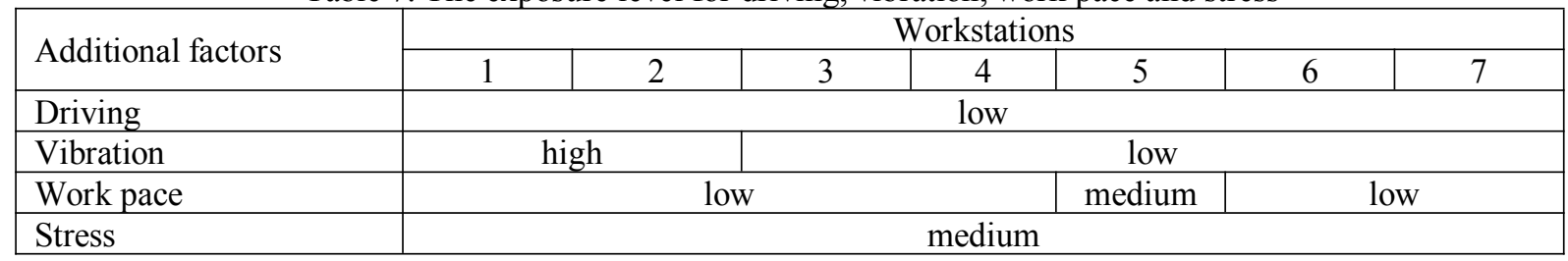

For every workstation, the driving scores were low. Vibration scores for two stations were high, and for five stations low, whilst the working pace scores were medium for one station, and low for six stations. Stress scores were evaluated as medium at every station.

Table 8 presents the obtained exposure level E and action level. At one station the exposure to risk of WRMSDs was very high, whilst for six stations it was high.

Table 8. The exposure level E and action level

\begin{tabular}{ccc}
\hline Workstations & QEC Score (E) $(\%)$ & Action level \\
\hline 1 & 75 & investigate and change immediately \\
2 & 64 & investigate further and change soon \\
3 & 63 & investigate further and change soon \\
4 & 58 & investigate further and change soon \\
5 & 60 & investigate further and change soon \\
6 & 63 & investigate further and change soon \\
7 & 69 & investigate further and change soon \\
\hline
\end{tabular}

\section{Discussion}

This study was conducted to assess and investigate the exposure level to risk for WRMSDs in the production line of frozen food products. The main findings of this study show that employees were exposed to very high risk for WRMSDs in the back (at workstation No. 1) and neck (workstations: 5, 
$6,7)$. There was a high exposure to risk factors in the back (workstations: $2,6,7$ ), shoulder/arm (workstations: 1, 3, 4, 5, 7), wrist/hand (workstations: 1, 2, 3, 5, 7) and neck (workstations: 1, 2, 3, 4) and a high exposure risk to vibration (workstations: 1,2). These high risks were associated with: highly repetitive tasks, awkward working postures, handling heavy loads, the use of considerable force, the eight-hour work shift, lack of rest and vibration. These can all bring about musculoskeletal complaints $[26,27]$.

The results of exposure level E of WRMSD assessment showed that the QEC scores obtained from the evaluated workstations ranged from $58 \%$ to $75 \%$, which means that risks were classified as high and very high. Similar results were obtained in a sugar producing factory [27]. For $99 \%$ of the workers, the exposure levels E were high and very high. Awkward postures and manual material handling were the main ergonomic problems encountered in this study. The results of this study indicate that the tasks and working conditions in the production workshops were conducive to the development of WRMSDs. Therefore, ergonomic interventions to improve the working conditions and to decrease the exposure level were necessary soon or immediately. Many studies exist that indicate that ergonomic interventions are needed and effective at reducing the workload and risks of musculoskeletal disorders $[29,30,31]$.

\section{Conclusions and recommendations}

The results demonstrated that the exposure level to risk factors for musculoskeletal disorders was high or very high in the production line of frozen food products. Awkward postures, manual handling of heavy loads, repetitive movements and vibration are the suspected risk factors for WRMSDs. Any ergonomic intervention program in the workplace should focus on eliminating awkward postures and manual handling of heavy loads and implementing job rotation in the production line.

Recommendations:

- The use of technical measures such as a conveyor belt for heavy loads (e.g. sacks of ingredients).

- Reducing the weight of the sacks of ingredients that are handled manually.

- Use height-adjustable lifts for sacks of ingredients.

- Develop an appropriate system of breaks in the work.

- Design a system of employee positions rotation.

\section{Acknowledgement}

The authors would like to thank the Manager and employees for the cooperation and help in carrying out the evaluation.

\section{References}

[1] Lasota A. Dolegliwości mięśniowo-szkieletowe szwaczek maszynowych. In: Paluch R, et al. editors. Obciążenie układu ruchu. Przyczyny i skutki. Wrocław, Poland: Oficyna Wydawnicza Politechniki Wrocławskiej; (2008), p. 151-161.

[2] Lasota A. Dolegliwości zdrowotne projektantów pracujących na stanowiskach pracy wyposażonych w komputery. Zeszyty Naukowe Politechniki Poznańskiej. Organizacja i Zarządzanie Vol. 33 (2001), p. 73-77.

[3] Lasota A. Ergonomiczna ocena dolegliwości mięśniowo-szkieletowych operatorów stanowisk dyspozytorskich. In: Kowal E, editor. Dolegliwości zdrowotne a warunki pracy. Zielona Góra, Poland: Oficyna Wydawnicza Uniwersytetu Zielonogórskiego; (2008), p. 21-25.

[4] Baldwin ML. Reducing the costs of work-related musculoskeletal disorders: targeting strategies to chronic disability cases. J Electromyogr Kines Vol. 14(1) (2004), p. 33-41.

[5] Bhattacharya A. Costs of occupational musculoskeletal disorders (MSDs) in the United States. Int J Ind Ergonom Vol. 44(3) (2014), p. 448-454. 
[6] Piedrahita H. Costs of work-related musculoskeletal disorders (MSDs) in developing countries: Colombia case. Int J Occup Saf Ergo Vol. 12(4) (2006), p. 379-386.

[7] Kumar S. A conceptual model of overexertion, safety, and risk of injury in occupational settings. Hum Factors Vol. 36(2) (1994), p. 197-209.

[8] Vieira ER, Kumar S. Working postures: a literature review. J Occup Rehabil. Vol. 14(2), (2004), p. 143-59.

[9] Black JT. Design rules for implementing the Toyota Production System. Int J Prod Res. Vol. 45(16) (2007), p. 3639-3664.

[10] Karhu O, Kansi P, Kuorinka I. Correcting working postures in industry: a practical method for analysis. Appl Ergon. Vol. 8(4) (1977), p. 199-201.

[11] McAtamney L, Corlett EN. RULA: a survey method for the investigation of work-related upper limb disorders. Appl Ergon. Vol. 24(2) (1993), p. 91-99.

[12]Hignett S, McAtamney L. Rapid Entire Body Assessment (REBA). Appl Ergon. Vol. 31(2) (2000), p. 201-205.

[13]David G, Woods V, Buckle P. Further Development of the Usability and Validity of the Quick Exposure Check (QEC). Research Report: RR211/2005. Sudbury, Suffolk, HSE Books; (2005).

[14]David G, Woods V, Li G, Buckle P. The development of the Quick Exposure Check (QEC) for assessing exposure to risk factors for work-related musculoskeletal disorders. Appl Ergon. Vol. 39(1) (2008), p. 57-69.

[15] Kee D, Karwowski W. A Comparison of three observational techniques for assessing postural loads in industry. Int J Occup Saf Ergo. Vol. 13(1) (2007), p. 3-14.

[16]Lasota AM. Analysis of packers' workload on the packing line - a case study. LogForum Vol. 10(4) (2014), p. 383-392.

[17]Lasota AM. Analiza obciążenia pracą metodą OWAS. Zarządzanie Przedsiębiorstwem Vol. 16(3) (2013), p. 35-39.

[18]Lasota AM. Obciążenie układu mięśniowo-szkieletowego operatorów w procesie produkcji części samochodowych. Zeszyty Naukowe Wyższej Szkoły Zarządzania Ochroną Pracy w Katowicach Vol. 10(1) (2014), p. 41-52.

[19]Lasota AM. A Reba-based analysis of packers workload: a case study. LogForum Vol. 10(1) (2014), p. 87-95.

[20]Lasota AM, Ścigaj M. Workload analysis of assembly positions. In: Dudarski G, Martinka J, Rybakowski M, Turekova I, editors. Modern trends in ergonomics and occupational safety: selected problems. Zielona Góra, Poland: Publishing House of The University of Zielona Góra; (2013), p. 45-54.

[21]Lasota AM, Hankiewicz K. Ryzyko i obciążenie statyczne operatorów wiertarek stołowych. Logistyka Vol. 5 (2014), p. 904-909.

[22] Lasota AM, Hankiewicz K. Working postures of operators in the pipe production process - a case study. Logistyka Vol. 6 (2014), p. 14417-14423.

[23] Lasota AM, Hankiewicz K. Ergonomiczna ocena pozycji przy pracy w procesie cięcia i pakowania materiałów termoizolacyjnych. Logistyka Vol. 5 (2015), p. 1059-1065.

[24]Butlewski M., Tytyk E., The assessment criteria of the ergonomic quality of anthropotechnical mega-systems; p. 298-306, [in]: Advances in Social and Organizational Factors, Edited by Peter 
Vink, CRC Press, Taylor and Francis Group, Boca Raton, London, New York, (2012), ISBN 978-1-4398-8

[25]Li G, Buckle P. Quick Exposure Checklist (QEC) for the Assessment of Workplace Risks for Work-Related Musculoskeletal Disorders (WMSDs). In: Stanton NA, Hedge A, Brookhuis K, Salas E, Hendrick HW, editors. Handbook of human factors and ergonomics methods. Boca Raton London New York Washington, D.C.: CRC Press, (2004). p. 6-1 - 6-10

[26]Bernard BP, Putz-Anderson V, Burt SE. A critical review of epidemiologic evidence for work-related musculoskeletal disorders of the neck, upper extremity, and low back. Cincinnati: Centers for Disease Control and Prevention National Institute for Occupational Safety and Health publication. (1997), p. 97-141.

[27] Westgaard RH. Work-related musculoskeletal complaints: some ergonomics challenges upon the start of a new century. Appl Ergon. Vol. 31(6) (2000), p. 569-580.

[28] Choobineh A, Tabatabaee SH, Behzadi M. Musculoskeletal problems among workers of an Iranian sugar-producing factory. Int J Occup Saf Ergo. Vol. 15(4) (2009), p. 419-424.

[29] Earle-Richardson G, Jenkins P, Fulmer S, Mason C, Burdick P, May J. An ergonomic intervention to reduce back strain among apple harvest workers in New York State. Appl Ergon. Vol. 36(3) (2005), p. 327-334.

[30]Lewis RJ, Krawiec M, Confer E, Agopsowicz D, Crandall E. Musculoskeletal disorder worker compensation costs and injuries before and after an office ergonomics program. Int $\mathrm{J}$ Ind Ergonom. Vol. 29(2) (2002), p. 95-99.

[31] Southard SA, Freeman JH, Drum JE, Mirka GA. Ergonomic interventions for the reduction of back and shoulder biomechanical loading when weighing calves. Int J Ind Ergonom. Vol. 37(2) (2007), p. 103-110. 